\title{
CUTTING STONE BUILDING MATERIALS WITH CUT WHEELS OF CUBIC BORON NITRIDE
}

\author{
A. Bespalova ${ }^{1}$, O. Dashkovskaya ${ }^{1}$, O. Faizulyna ${ }^{1}$, V. Lebedev ${ }^{2}$, T. Chumachenko ${ }^{2}$ \\ ${ }^{I}$ Odessa State Academy of Civil Engineering and Architecture \\ ${ }^{2}$ Odessa Polytechnic National University
}

Abstract: The advantage of cutting stone building materials with SSM (synthetic superhard materials) wheels is that, first of all, it is possible to obtain high processing productivity and dimensional stability, which are $3 . .5$ and $50 \ldots 100$ times higher than those of traditional tools based on carborundum, respectively.

The study of the process of cutting stone materials with CBN (cubic boron nitrite) wheels is aimed at establishing force dependences, determining the cutting power and heating temperature of the cutting disc during operation.

The forces were measured using a tensometric dynamometer UDM-50. To measure and calculate the cutting temperature, a thermoelectric method based on the formation of practically not inertial microthermocouples during cutting was used.

The temperature to which the CBN cutting wheel on a metal base is heated is a limiting factor in processing, since when heated to a temperature of $600^{\circ} \mathrm{C}$, the strength of the wheel decreases by half, which can cause its rupture under the action of centrifugal forces, as well as loss of stability and jamming during cutting. In the present study, the wheel temperature was measured after one minute of continuous operation.

The values of the component of the cutting force PY, depending on the processing modes, can reach values of the order of $70 \mathrm{~N}$. The values of the component of the cutting force PZ, depending on the processing modes, can reach values of $45 \mathrm{~N}$. The cutting power can be $2800 \mathrm{~W}$.

The temperature resistance of the wheel (heating time of the wheel up to $600^{\circ} \mathrm{C}$ ) when cutting dry is maximum 28 minutes, when grinding with cooling of the cutting zone with negative temperature air from a Ranque-Hilsch tube, the temperature resistance is 35 minutes, with ejector cooling of sprayed coolant 37 minutes and with jet-pressure cooling it is 40 minutes. The maximum cutting length is respectively $0.7: 0.8 ; 0.9$ and $2 \mathrm{~m}$. The cutting power is $600 \ldots 2800 \mathrm{~W}$.

Keywords: stone building materials, cutting, synthetic superhard materials, cut-off wheel, cubic boron nitride, cutting forces, wheel temperature.

\section{РОЗРІЗАННЯ КАМ'ЯНИХ БУДІВЕЛЬНИХ МАТЕРІАЛІВ ВІДРІЗНИМИ КРУГАМИ З КУБІЧНОГО НІТРИДУ БОРУ}

\author{
Беспалова А. В. ${ }^{1}$, Дашковська О. П. ${ }^{1}$, Файзулина О. А. ${ }^{1}$, Лебедсв В. Г. ${ }^{2}$, \\ Чумаченко T. B. ${ }^{2}$ \\ ${ }^{1}$ Одеська державна академія будівництва та архітектури \\ ${ }^{2}$ Одеський наиіональный університет «Одеська політехніка»
}

Анотація: Перевага розрізання кам'яних будівельних матеріалів кругами СНM (синтетичні надтверді матеріали) полягає, насамперед, у можливості отримувати високу продуктивність обробки та розмірної стійкості, що перевищують аналогічні показники традиційних інструментів на основі карборунду відповідно в $3 . .5$ і $50 \ldots 100$ разів.

Дослідження процесу розрізання кам'яних матеріалів кругами 3 КНБ спрямоване на встановлення силових залежностей, визначення потужності різання і температури нагрівання відрізного диску під час роботи. 
Сили вимірювалися за допомогою тензометричного динамометра УДМ-50. Для вимірювання та розрахунку температури різання у роботі використаний термоелектричний метод, заснований на утворенні практично безінерційних мікротермопарів у процесі різання.

Температура, до якої нагрівається ріжучий круг на металевій основі, є лімітуючим фактором обробки, оскільки при нагріванні до температури $600^{\circ} \mathrm{C}$ міцність круга зменшується вдвічі, що може викликати його розрив під дією відцентрових сил, а також втрату стійкості та заклинювання при різанні. У цьому дослідженні температура круга вимірювалася після хвилини безперервної роботи.

Значення складової сили різання РY в залежності від режимів обробки можуть досягати значень порядку 70N. Значення складової сили різання $\mathrm{PZ}$, залежно від режимів обробки, можуть досягати значень 45N. Потужність різання може становити $2800 \mathrm{~B}$.

Температурна стійкість круга (час нагрівання круга до $600^{\circ} \mathrm{C}$ ) при розрізанні всуху становить максимально 28 хвилин, при шліфуванні з охолодженням зони різання повітрям негативної температури з трубки Ранка-Хілша температурна стійкість складає 35 хвилин, і при струменево-напірному охолодженні становить 40 хвилин. Максимальна довжина різу становить відповідно величини 0,7: 0.8; 0,9 та 2м. Потужність різання становить величини 600...2800Вт.

Ключові слова: кам'яні будівельні матеріали, розрізання, синтетичні надтверді матеріали, відрізний круг, кубічний нітрид бору, сили різання, температура круга. 


\section{INTRODUCTION}

During the reconstruction and repair of buildings and structures and the restoration of old buildings or cultural monuments, it becomes necessary to cut, form new holes in the walls, make cut slots, correct deformed parts, eliminate those structural elements that have collapsed or have undergone significant wear over time and chemical influence of the external environment.

Also, it is often necessary to strengthen structures that have great destruction. In this case, it is necessary to introduce auxiliary structures into walls, foundations and floors, for which it is necessary to punch openings and nests in them, where reinforcing elements are inserted. Such work is often performed in shell limestone, concrete, reinforced concrete, hard materials - granite, basalt, etc. by cutting or making cuts to the required size with cutting wheels made of synthetic superhard materials. (SSM-synthetic diamond, cubic boron nitride).

The advantage of cutting stone building materials with SSM wheels is that, first of all, it is possible to obtain high processing productivity and dimensional stability, exceeding those of traditional tools based on carborundum by a factor of $3 \ldots 5$ and $50 \ldots 100$, respectively. For example, if the productivity of cutting hard stone with carborundum discs is on average $100 \ldots 150 \mathrm{~cm}^{3} / \mathrm{min}$, then with diamond and CBN discs it is $400-600 \mathrm{~cm}^{3} / \mathrm{min}$. At the same time, the accuracy of the operation and the quality of the processed surface are significantly increased. The surface obtained after cutting does not need further polishing, which is very important when carrying out repair work.

The negative aspects of this process are the limitation of the operating time of the wheel due to its heating, which leads to a loss of strength and an increase in the consumption of the layer from the SSM due to the high heating of the cutting wheel and to the loss of the ability to control the process due to intense dust formation, which sharply reduces the visibility of the production area. All this makes it necessary to periodically interrupt the cutting process.

The process of cutting stone materials with diamond cut-off wheels is currently well studied, while the process of cutting these materials with $\mathrm{CBN}$ wheels is practically not studied, although CBN has a number of significant advantages.

$\mathrm{CBN}$ is a superhard synthetic material consisting of nitrogen and boron atoms forming a tetragonal crystal lattice similar to the crystal lattice of diamond. It has high hardness - up to $9500 \mathrm{kgf} / \mathrm{mm}^{2}$ (about $5 \%$ less than diamond), high heat resistance $\left(1400^{\circ} \mathrm{C}\right)$, chemically inert with respect to carbon-containing materials and more durable than diamond (bending strength up to $100 \mathrm{kgf} / \mathrm{mm}^{2}$ ), (Table $\left.1[1]\right)$.

Table 1

Comparative properties of abrasive materials.

\begin{tabular}{|c|c|c|}
\hline Material & Microhardness $\times 10^{2}, \mathrm{MPa}$ & Temperature stability,${ }^{\circ} \mathrm{C}$ \\
\hline Diamond & 1000 & $650-700$ \\
\hline CBN & $850-950$ & $1100-1300$ \\
\hline
\end{tabular}

The tool life of CBN discs is 2-3 times higher than that of diamond discs.

Since CBN has a high temperature stability, then obviously the operating time of the cutting wheel on a metal bond will depend only on heating of the wheel to a temperature of $600^{\circ} \mathrm{C}$ at which the strength of the metal disk decreases by 2 times and there is a real danger of the disk breaking.

Therefore, the study of the process of cutting stone materials with CBN wheels should be aimed at establishing power dependencies, at determining the cutting power and heating temperature of the cutting disc during operation. To do this, it is necessary to determine the patterns of change in cutting forces, cutting power, heating temperature of the cutting disc, and also to determine the productivity (length of the cut) for the period of operation before the 
disc is heated to a temperature of about $600^{\circ} \mathrm{C}$.

\section{LITERATURE REVIEW}

It should be noted that in the modern literature there is no clear data on cutting with these wheels. It is noted that the contact temperature of grinding is generally lower than when grinding with conventional ceramic wheels. There is little information on cutting forces, temperature, and cutting power when cutting with CBN wheels of stone and ceramic materials, and they are contradictory.

So in work [2] new CBN wheels are considered and some questions of their application are considered. However, the issues of cutting stone materials are not considered.

In work [3] the process of grinding with CBN wheels is considered in detail.

However, the process of cutting stone materials with these wheels is not considered. The authors of [4] consider the issues of grinding high-ductility alloys with CBN wheels. However, this work does not touch upon the issues of cutting stone materials.

Work [1] is devoted to the study of processing by grinding with CBN wheels of aluminum alloys. The cutting of stone materials and ceramics has not been investigated.

The article [5] discusses the issues of grinding without cooling with CBN wheels of various alloys. However, the issue of cutting of stone materials and ceramics is not considered. In addition, the authors measure not the grinding temperature, but the average temperature of the part before and after grinding, which provides little information of process.

The authors of the research in publication [6] consider the issues of grinding with highly porous $\mathrm{CBN}$ wheels, but the issues of cutting stone materials and ceramics are not considered.

In [7], the process of grinding with highly porous CBN wheels is considered in terms of minimizing the number of edits, and high porosity is considered as a means of delivering coolant to the cutting zone. The issues of cutting stone materials and ceramics are not considered.

The issues of grinding difficult-to-machine materials with CBN wheels - titanium and nickel alloys, as well as the issues of determining the most advantageous porosity of the wheel from the point of view of maintaining grain holding forces by the binder are considered in [8]. It was shown that the best results were shown by a porosity of $30 \%$. The issue of cutting stone materials and ceramics has not been studied.

The authors of [9] investigate the process of profile gear grinding with highly porous abrasive wheels. Data on a decrease in cutting power and an increase in the accuracy of ground gears have been recorded. However, in this work only abrasive wheels are considered and there is no information about the cutting of stone materials and ceramics.

In [10], numerical and mathematical models are considered for determining the thermomechanical state of structurally inhomogeneous materials. Simulation of thermomechanical processes makes it possible to obtain a criterion relation for the condition of a balanced state of a defect depending on the gradients of the contact temperature. However, the work does not specifically address the processes of cutting with CBN wheels.

The purpose of work [11] is to study the processes of heat transfer during abrasive processing of parts by constructing the temperature field of the system grinding wheel workpiece for various characteristics of the grinding mode. But in this work, the issue of modeling the cutting process in relation to stone materials is not considered.

It can be concluded that, despite the large number of works carried out on the study of the grinding process with CBN wheels, the issues of cutting stone materials have not been clarified. The issue of grinding ceramics has practically not been considered.

It can be argued that at present there are no recommendations for cutting stone materials with CBN wheels that would provide the highest thermal resistance of the wheel. 


\section{RESEARCH METHODOLOGY}

Based on the foregoing, in this work, mathematical modeling of the process of stone materials by $\mathrm{CBN}$ circles was carried out with a point experimental verification of the results.

The main goals set in this work are as follows:

1. Investigate the energy characteristics of the process - cutting power and cutting forces.

2. Investigate the thermodynamic characteristics of the process - temperatures, heating of the circle and the thermal resistance of the circle

3. Determine the processing performance depending on the characteristics of the wheels and cutting modes.

\section{Methodological features of the study.}

Measuring cutting forces.

In this work, the cutting forces, in addition to mathematical modeling, were determined experimentally, which made it possible to check the mathematical model and obtain real values of the forces.

The forces were measured using a tensometric dynamometer UDM-50.

The principle of operation of the device is as follows: A general view of the dynamometer and a cross-section of a general view are shown in Fig. 1 and Fig. 2 respectively.

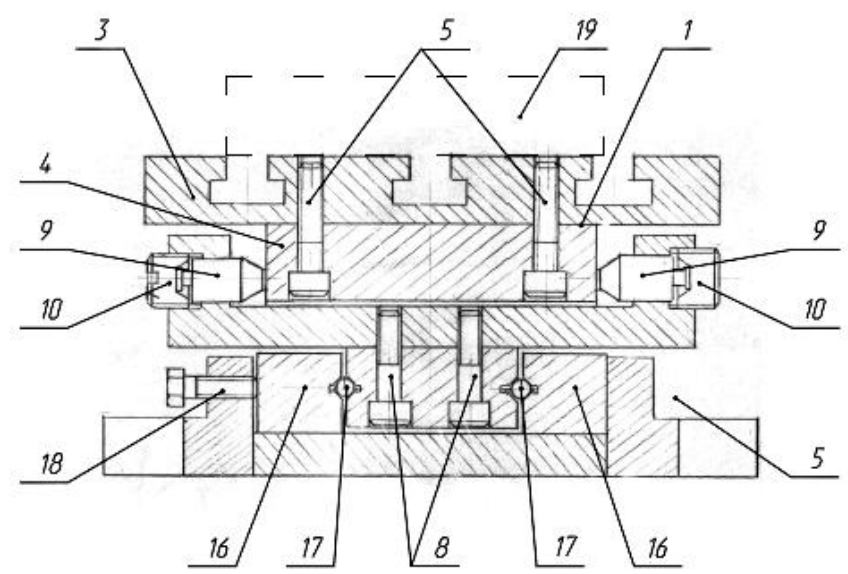

Fig. 1. Longitudinal section of the general view of the dynamometer

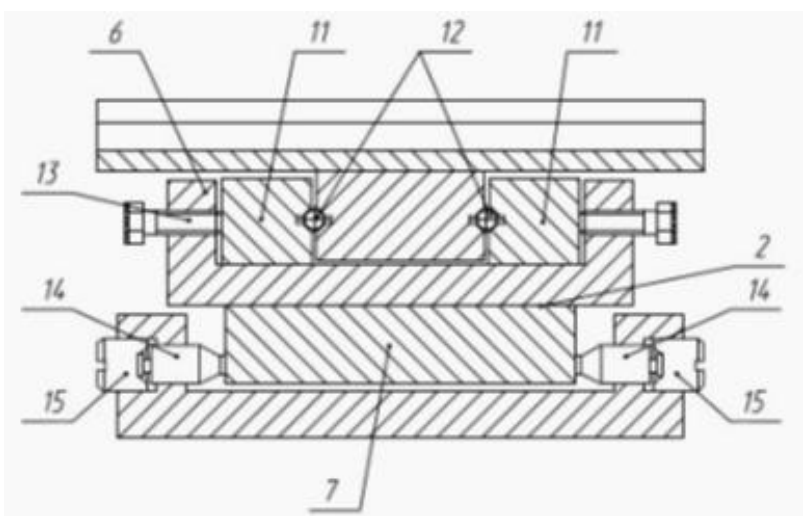

Fig. 2. Cross section of the general view of the dynamometer

The principle of operation of a two-component dynamometer for measuring the components of the cutting force is as follows.

The dynamometer is installed on the machine, after which the workpiece 19 is fixed on the loading tool 1 , the preload of the strain gauges 9 and strain gauges 14 is carried out using 
the pins 10 and pins 15; rigid fixation of the prismatic guides 11 and the prismatic guides 16 is carried out using the tightening bolts 13 and the tightening bolts 18 . Under the action of the cutting force, which is decomposed into the measured components, the corresponding load tables 1 and 2 move. The load tables 1 and 2 move longitudinally through the steel balls 12 and 17 along the prismatic guides 11 and 16 act on the strain gauges 9 and strain gauges 14 . The signal is output to a detachable chassis (not shown in the drawing) connected to an amplifier.

The device makes it possible to provide the ability to accurately measure the components of the cutting force regardless of the position of the workpiece on the loading table relative to the center of the dynamometer, which ultimately increases the ease of use and visibility of tests.

We calibrate the device with weights along the vertical and horizontal components. The signal from the amplifier is fed to the ADC, after which it is displayed on the tablet.

\section{Cutting temperature measurement.}

To measure and calculate the indicated data, a thermoelectric method based on the formation of practically not inertial microthermocouples during cutting was used.

Considering that almost all stone materials are non-conductive in temperature measurements, the method of artificial thermocouple is applied. One electrode is a steel foil and a constantan foil is used as the second electrode. The thickness of the foil leaves is from $6 . . .20$ microns, and the distance between them is of the order of 40 microns or less, depending on the thickness of the capacitor paper, which isolates them from each other. In order for a stable formation of a thermal junction to occur during cutting, the thermoelectrodes are annealed at a temperature $1000 \ldots 1100^{\circ} \mathrm{C}$ for $30 \mathrm{~min}$. The ends are brought to the surface and welded together during cutting. As a result, a thermal spike with a thickness of $2 \ldots 3$ microns appears and, therefore, a thermocouple of the "iron-constantan" type is formed, which has a very low inertia. Since most CBN discs are made on a metal basis, the closure of the lobes of such a thermocouple can be carried out directly by the wheel. In addition, you can use a single lobe thermocouple of the thermo-lobe type - a cutting metal wheel. In this case, due to the simplification of the design of the thermocouple, the signal pickup circuit is complicated for which rotating current collectors or radio channel ones can be used, which is not difficult in modern conditions.

Such a thermocouple is calibrated according to the reference method described in [12].

The test sample consists of two halves (Fig 3). The plane of the connector is located normal to the ground surface and normal to the trajectory of the heat source (cut surface) Between the thermoelectrodes there is an insulator (capacitor paper) with a thermal conductivity of no more than $0.1 \mathrm{~W} / \mathrm{m}^{2} \times \mathrm{deg}$.

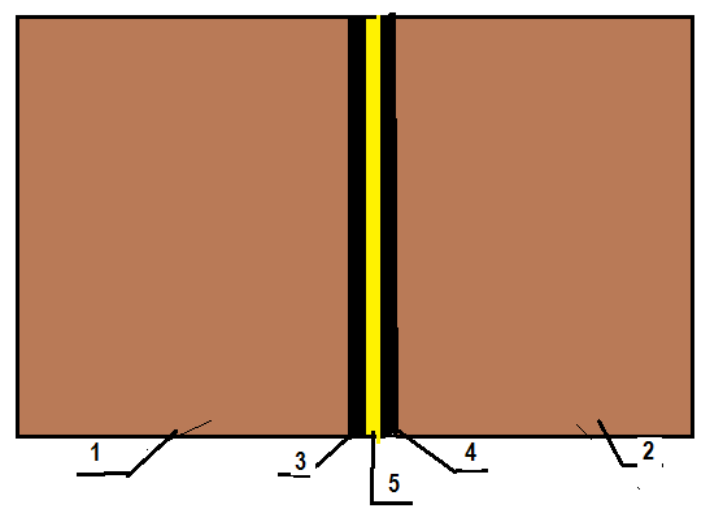

a)

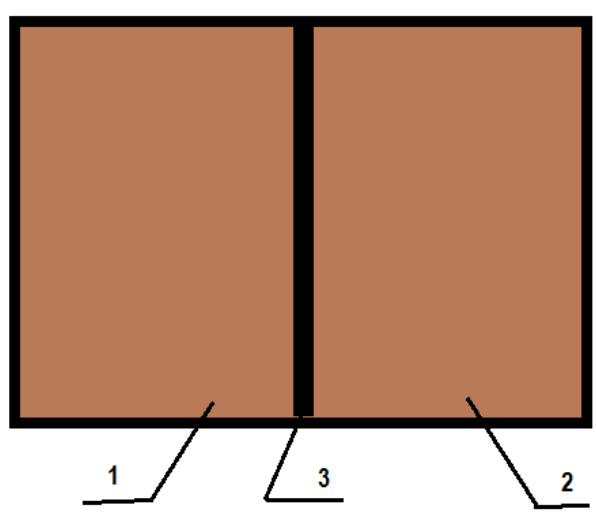

b)

Fig 3. a) 1,2 - halves of a stone specimen, 3, 4- thermoelectrode foil, 5-insulator; b) 1,2 - halves of a stone specimen, 3 - thermoelectrode foil 
Thermoelectrodes in the form of a foil are brought out to the surface of the sample and, when cut, are connected to each other, forming a thermal junction, the thickness of which is 510 microns, thus forming a low-inertia microthermocouple, which provides the following characteristics of the measuring system:

- sensitivity - from 1 to $150 \mathrm{mV} / 100^{\circ} \mathrm{C}$;

- frequency range $0 \div 2 \mathrm{MHz}$;

- the duration of the transmitted pulse from $1 \mu \mathrm{s}$.

The signal amplified in voltage by 2000 times is fed to an analog-to-digital converter with a frequency of at least $200 \mathrm{MHz}$, where it is converted into a digital code, and then fed to a computer. A conversion takes place on the computer, as a result of which a thermal impulse and the maximum digital value of the temperature in degrees Celsius are recorded on the display.

A heat source with the same intensity acts on the cut surface of the stone and the end face of the embedded thermocouple in the cutting zone, and the heat dissipation due to the inequality between the thermal activity coefficients of the stone being cut and the embedded thermocouple is different and leads to a corresponding difference in contact temperatures in the grinding zone of the processed material and the embedded thermocouple. The input signal of such a thermocouple does not correspond to either the contact temperature of the cut stone or the embedded thermocouple.

Using the data [17], we determine the true temperature of the circle by the expression:

$$
T_{\kappa}=T_{n} \frac{\varepsilon_{n}+\varepsilon_{m}}{2 \cdot \varepsilon_{n}},
$$

where $\varepsilon_{n}$ and $\varepsilon_{n}$, respectively, are the coefficients of thermal activity of the stone and microsolder, $\mathrm{j} / \mathrm{m}^{2}{ }^{\circ} \mathrm{C} \mathrm{s}{ }^{0.5}: \varepsilon_{n}$ - coefficient of thermal activity of the stone; $\varepsilon_{m}$ - coefficient of thermal activity of thermal junction.

In the case of using the circuit according to Fig. 3,b, a thermocouple "thermoelectrode foil - metal circle" is created during cutting. This scheme requires careful calibration of such a thermocouple and a more complex current collector rotating device.

The results of measurements of forces, power, cutting temperature and maximum cutting length are shown in Fig. 4, 5, 6, 7 [13].

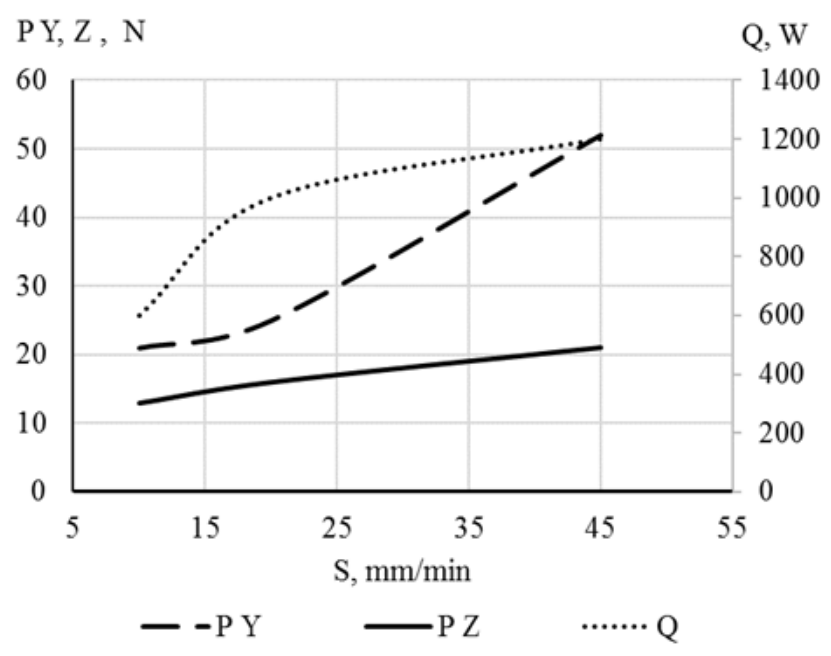

Fig. 4. Dependence of cutting forces $\mathrm{Py}, \mathrm{Pz}$ and cutting power $\mathrm{N}$ versus minute feed. Wheel LO 250/160 100\% 


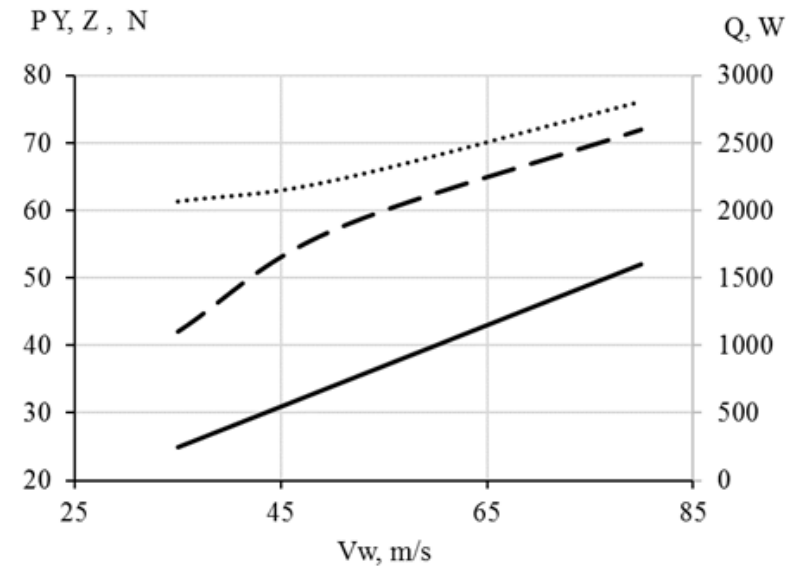

$-\mathrm{PY} \quad \longrightarrow \mathrm{PZ} \quad \cdots \cdots \cdot \mathrm{Q}$

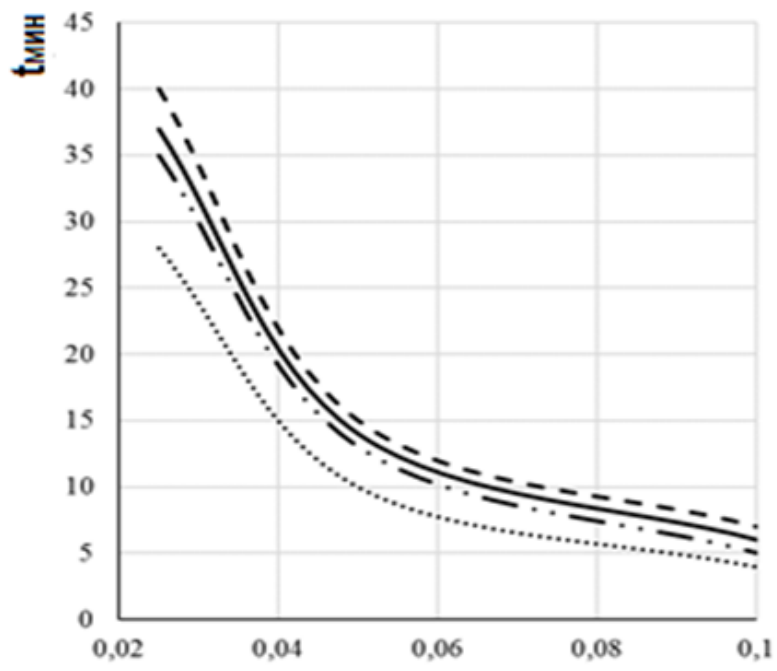

$\begin{array}{ll}\cdots \cdots & 1 \mathrm{~T} \\ -3 \mathrm{~T} & --\mathrm{T}^{4}\end{array}$

$\mathrm{S}, \mathrm{m} / \mathrm{min}$

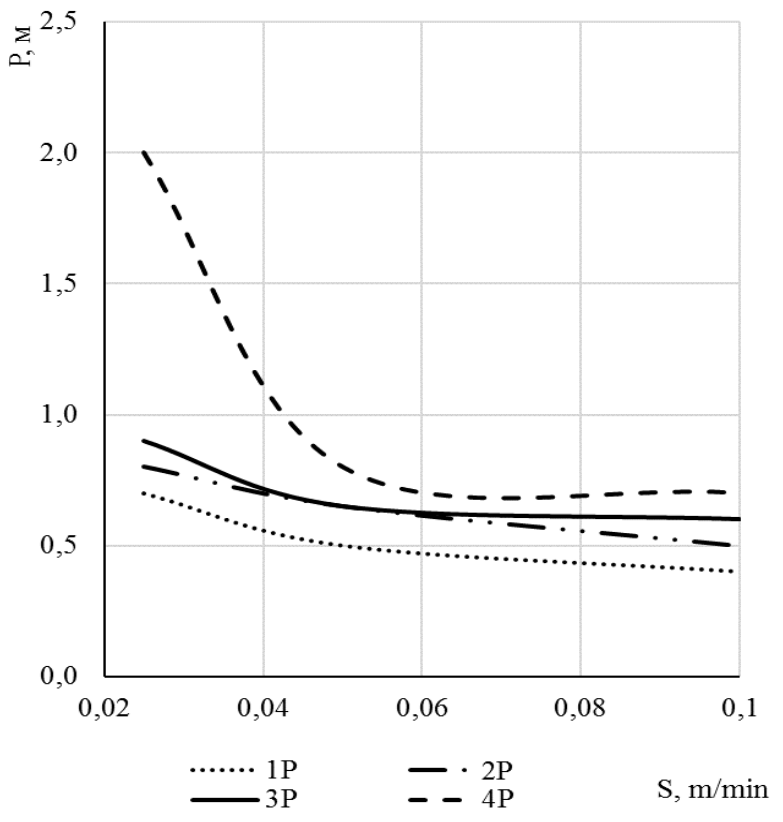

Fig. 5. Dependence of forces Py, Pz and cutting power $\mathrm{N}$ versus speed of a wheel.Wheel LO 250/160 100\%

Fig. 6. Dependence of the lap time to heating $600^{\circ} \mathrm{C}$

1T - without cooling; 2T - with cooling Ranque-Hilsch tube; $3 \mathrm{~T}$ - ejector cooling; $4 \mathrm{~T}$ - pressure jet

Fig. 7. Dependence of the maximum cutting length of a wheel up to heating $600^{\circ} \mathrm{C}$ $1 \mathrm{P}$ - without cooling; $2 \mathrm{P}$ - with cooling Ranque-Hilsch tube; $3 \mathrm{P}$ - ejector cooling; $4 \mathrm{P}$ - pressure jet 
As can be seen from the graphs given, the force PY can be in the region of $52 \ldots 72 \mathrm{~N}$, depending on the minute feed and the cutting speed. The cutting force Pz has values from 45 to $20 \mathrm{~N}$, also depending on the cutting modes. Accordingly, the values of thermal power have the following values: $1200 \ldots 2800 \mathrm{~W}$.

The temperature to which the CBN wheel is heated for a cutting wheel on a metal base is a limiting factor in processing, since when heated to a temperature of $600^{\circ} \mathrm{C}$, the strength of the wheel decreases by half, which can cause its rupture under the action of centrifugal forces, as well as loss of stability and jamming during cutting.

In the present study, the wheel temperature was measured after one minute of continuous operation. The temperature measuring system allowed the temperature to be monitored continuously during cutting.

It should be noted that in this case we are talking about the contact temperature. In order to get the temperature of the circle, it is necessary to take into account the expression 1.

When cutting with $\mathrm{CBN}$ wheel without cooling, the time of its heating to a temperature of $600^{\circ} \mathrm{C}$ is in the range from 4 to 28 minutes, depending on the value of the minute feed. It should be noted that the longest cut length during heating to the critical temperature occurs at the minimum feed.

Cooling of the cutting wheel with a Ranque-Hilsch tube is shown in Fig. 5, curve 2.

Cooling occurs as follows.

Air cooled to $-40^{\circ} \mathrm{C}$ leaves the "cold shoulder" of the Rank-Hilsch tube. The RankaHilsch tube is a cheap and small-sized device that, when connected to a compressor, creates an air flow with a temperature of $-40^{\circ} \mathrm{C}$. The use of other cooling media, such as liquid nitrogen or solid carbon dioxide, complicates and increases the cost of the cooling process.

For industrial use, this temperature reduction is simple and minimally energy intensive.

The vortex effect of a tube (Rank-Hilsch effect) is the effect of the separation of a gas or liquid into two fractions when twisted in a cylindrical or conical chamber (Fig. 8). A swirling flow with a high temperature $\left(+110^{\circ} \mathrm{C}\right)$ is formed at the periphery, and a cooled flow swirling in the opposite direction $\left(-40^{\circ} \mathrm{C}\right)$ in the center (Fig. 6). An explanation of this effect is given in the sources $[14,15]$.

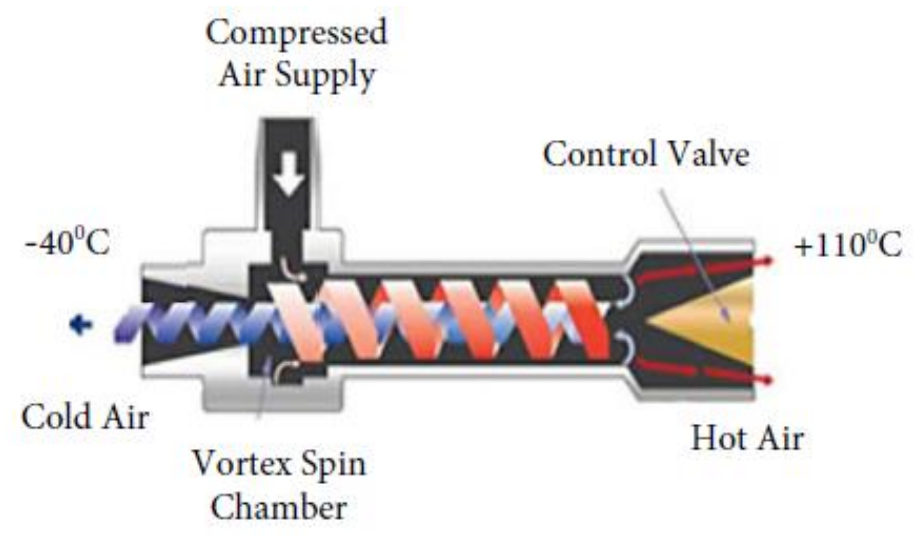

Fig. 8. Ranque-Hilsch tube [14]

The tube is connected to the pneumatic system of the workshop (pressure $6 \mathrm{~kg} / \mathrm{cm}^{2}$ ), as a result of which cold and hot air can be obtained without any additional devices.

A jet of cold air is supplied tangentially to the wheel, thus replacing the "warm" boundary layer. Contact heat exchange is carried out between the wheel and the new boundary layer. As can be seen from Fig. 6, curve 2, the time of the heat resistance of the wheel increases to $35 \mathrm{~min}$ and the length of the cut increases to $0.8 \mathrm{~m}$. This increase has large values in the region of small feeds.

Ejector cooling of the cutting zone has almost the same effect as cooling with a RanqueHilsch tube. 
The use of jet-pressure cooling - curve 4 provides a sharp increase in both the thermal resistance and the length of the cut almost 2 times compared with the previous cutting methods.

\section{RESULTS}

As a result of the study of the process of cutting stone materials with wheels of CBN, it was established:

The values $f$ the component of the cutting force PY, depending on the processing modes, can reach values of the order of $70 \mathrm{~N}$. The values of the component of the cutting force PZ, depending on the processing modes, can reach values of $45 \mathrm{~N}$. The cutting power can be $2800 \mathrm{~W}$.

When compared with cutting with diamond wheels, these values are about $10 \%$ higher.

The temperature resistance of the wheel (heating time of the wheel up to $600^{\circ} \mathrm{C}$ ) when cutting dry is maximum 28 minutes, when grinding with cooling of the cutting zone with negative temperature air from a Ranque-Hilsch tube, the temperature resistance is 35 minutes, with ejector cooling of sprayed coolant 37 minutes and with jet-pressure cooling it is 40 minutes. The maximum cutting length is respectively $0.7: 0.8 ; 0.9$ and $2 \mathrm{~m}$.

The cutting power is $600 \ldots 2800 \mathrm{~W}$.

\section{CONCLUSIONS}

Cutting stone building materials with $\mathrm{CBN}$ wheels allows good cutting results without cooling. When using means of cooling the working area, the thermal resistance of the wheel can reach 40 minutes, which allows you to make long cuts without interruption.

Despite the fact that CBN wheels are somewhat more expensive than diamond wheels, they can be recommended for use since the wear of these wheels is much lower than diamond wheels, and the characteristics of the cutting process differ slightly.

\section{References}

1. Starkov, V. (2013). Vysokoporistye krugi iz kubicheskogo nitrida bora dlya shlifovaniya bez ohlazhdeniya. [Highly porous cubic boron nitride wheels for dry grinding]. Sverhtverdye materialy. 5. 56-62. [in Russian].

2. Kremen, Z. (2003). A new generation of high-porous vitrified CBN wheels. Industrial Diamond Review. 63(4). 53-56.

3. Starkov, V. (2007). Shlifovanie vysokoporistymi krugami. [Grinding with highly porous discs]. M.: Mashinostroenie. [in Russian].

4. Kremen, Z., Zubarev, Yu., Lebedev, A. (2009). Vysokoporistye krugi iz el'bora i ih primenenie pri shlifovanii vysokoplastichnyh splavov. [ Highly porous CBN wheels and their use in grinding highplastic alloys]. Metalloobrabotka. 3 (51). 2-5. [in Russian].

5. Soler, Ya., Nguen, Ch. (2015). Ocenka shlifuemosti alyuminievyh splavov 1933t2 i V95ochT2 vysokoporistym krugom Norton 37c46k12vp po shagovym parametram mikronerovnostej. [The assessment sandability aluminum alloys $1933 \mathrm{~T} 2$ and V95ochT2 highly porous wheel for Norton 37C46K12VP steps parameters microughnesses]. International Scientific Review. 2 (3). 2015. 12-18. [in Russian].

6. Starkov, V. K., Ryabcev, S. A., Polkanov, E. G. (2004). Razrabotka i primenenie vysokoporistyh shlifoval'nyh krugov iz kubicheskogo nitrida bora. [Development and Application of Highly Porous Cubic Boron Nitride Grinding Wheels]. Tekhnologiya mashinostroeniya. 4. 26-33. [in Russian].

7. R. Cai, W. B. Rowe, Michael N. Morgan (2003). The Effect of Porosity on the Grinding Performance of Vitrified CBN Wheels. Key Engineering Materials. V. 238-239. 295-300. 
8. Zhenzhen, C., Jiuhua, X., Wenfeng, D., Changyu, M. (2014). Grinding Performance Evaluation of Porous Composite-bonded CBN Wheels for Inconel 718. Chinese Journal of Aeronautics. 27 (4). 1022-1029. doi: http://dx.doi.org/10.1016/j.cja.2014.03.015.

9. Larshin, V. P., Lishchenko, N. V., Ryabchenko, S. V., Nezhebovskiy, V. V., Sereda, G. V. (2016). Profil'noe shlifovanie zubchatyh kolyos vysokoporistymi abrazivnymi krugami. [Profile grinding of gear wheels with highly porous abrasive wheels]. Oborudovanie $i$ instrument. 5 (190). 20-23. [in Russian].

10.Usov, A. V. Sikirash, Yu. Ye. (2020). Modelyuvannya teplofizy`chny`x procesiv pry` mexanichnij obrobci vy`robiv iz strukturno neodnoridny`x materialiv. [Modeling of thermal processes in the mechanical processing of virobiv iz structurally non-universal materials]. Applied questions of mathematical modelling. 3. 2.1. 280-289. doi.org/10.32782/KNTU2618-0340/2020.3.2-1.26. [in Ukranian].

11.Tonkonogyi, V., Rybak, O. (2019). Modelling and experimental research of the heat transfer processes while grinding workpieces with plasma coatings. Cutting \& tools in technological systems. 90. 100-108. http://repository.kpi.kharkov.ua/handle/KhPI-Press/43881.

12.Lykov, A. V. (1967). Teoriya teploprovodnosti: uch. posobie. [Thermal Conductivity Theory: A Study Guide]. M.: Vysshaya shkola. [in Russian].

13.Bespalova, A., Lebedev, V., Tonkonogyi, V., Morozov, Y., Frolenkova, O. (2019). Cutting stone building materials and ceramic tiles with diamond disc. Procceedings of the 2nd International Conference jn Design, Simulation, Manufacturing: The Innovation Exchang. DSMIE-2019. $510-521$.

14.Horobryh, M. A., Klement'ev, V. A. (2012). Vihrevoj effekt Ranka-Hilsha. Vihrevaya truba. [Vortex Ranque-Hilsch effect. Vortex tube]. Molodoj uchenyj. 6. 54-55. [in Russian].

15.Korkodinov, Ya. A., Hurmatullin, O. G. (2012). Primenenie effekta Ranka-Hilsha. [Applying the Rank-Hilsch effect] Perm'. Vestnik Permskogo Nacional'nogo Issledovatel'skogo Politekhnicheskogo Universiteta. 14(4). 42-54. [in Russian].

\section{Література}

1. Старков В. Высокопористые круги из кубического нитрида бора для шлифования без охлаждения. Сверхтвердые материалы, 2013. №5. С. 56-62.

2. Kremen Z. A new generation of high-porous vitrified CBN wheels. Industrial Diamond Review 4 2003. P. 53-56.

3. Старков В. Шлифование высокопористыми кругами. М.: Машиностроение, 2007. 688 с.

4. Кремень 3., Зубарев Ю., Лебедев А. Высокопористые круги из эльбора и их применение при шлифовании высокопластичных сплавов. Металлообработка, 2009. №3 (51). С. 2-5

5. Солер Я., Нгуен Ч. Оценка шлифуемости алюминиевых сплавов 1933т2 и В95очТ2 высокопористым кругом Norton 37c46k12vp по шаговым параметрам микронеровностей. International scientific review, 2015. №2 (3). C. 12-18.

6. Старков В.К., Рябцев С.А., Полканов Е.Г. Разработка и применение высокопористых шлифовальных кругов из кубического нитрида бора. Технология машиностроения, 2004. №4. C. 26-33.

7. R. Cai et al., "The Effect of Porosity on the Grinding Performance of Vitrified CBN Wheels", Key Engineering Materials. 2003. V. 238-239. pp. 295-300.

8. Zhenzhen C., Jiuhua X., Wenfeng D., Changyu M. Grinding Performance Evaluation of Porous Composite-bonded CBN Wheels for Inconel 718. 2014. Chinese Journal of Aeronautics. 27 (4). 1022-1029. doi: http://dx.doi.org/10.1016/j.cja.2014.03.015.

9. Ларшин В. П., Лищенко Н. В., Рябченко С. В., Нежебовский В. В., Середа Г. В.. Профильное шлифование зубчатых колёс высокопористыми абразивными кругами. Оборудование и инструмент, 2016. №5 (190). С. 20-23.

10.Усов А.В. Сікіраш Ю.Є. Моделювання теплофізичних процесів при механічній обробці виробів із структурно неоднорідних матеріалів. Applied questions of mathematical modeling, 2020. №3. 2.1 C. 280-289. DOI:https://doi.org/10.32782/KNTU2618-0340/2020.3.2-1.26.

11.Tonkonogyi V., Rybak O. Modelling and experimental research of the heat transfer processes while grinding workpieces with plasma coatings. Cutting \& tools in technological systems. 2019. No 90. P. 100-108. http://repository.kpi.kharkov.ua/handle/KhPI-Press/43881. 
12.Лыков А.В. Теория теплопроводности: уч. пособие. М.: Высшая школа, 1967. 600 с.

13.Bespalova A., Lebedev V., Tonkonogyi V., Morozov Y., Frolenkova O. Cutting stone building materials and ceramic tiles with diamond disc. Procceedings of the 2nd International Conference jn Design, Simulation, Manufacturing: The Innovation Exchang. DSMIE-2019. Lutsk. June 11-14. 2019. P. 510-521.

14.Хоробрых М.А., Клементьев В.А. Вихревой эффект Ранка-Хилша. Вихревая труба. Молодой ученый, 2012. №6. С. 54-55.

15.Коркодинов Я.А., Хурматуллин О.Г. Применение эффекта Ранка-Хилша. Вестник пермского национального исследовательского политехнического университета. Машиностроение, материаловедение. Пермь, 2012. №.14(4). С.42-54.

\author{
Bespalova Alla \\ Odessa State Academy of Civil Engineering and Architecture \\ Doctor of Technical Science., Assosiate Professor \\ Didrihsona str., 4 Odessa, Ukraine, 65029 \\ bespalova.a.v.2015@gmail.com \\ ORCID: 0000-0003-3713-0610 \\ Dashkovskaya Olha \\ Odessa State Academy of Civil Engineering and Architecture \\ Ph.D., Assosiate Professor \\ Didrihsona str., 4 Odessa, Ukraine, 65029 \\ dop.od@ukr.net \\ ORCID: 0000-0002-9980-023X \\ Faizulyna Oksana \\ Odessa State Academy of Civil Engineering and Architecture \\ Ph.D., Assosiate Professor \\ Didrihsona str., 4 Odessa, Ukraine, 65029 \\ narenko@ukr.net \\ ORCID: 0000-0002-1151-4467 \\ Lebedev Volodymyr \\ Odessa Polytechnic National University \\ Doctor of Technical Science, Professor \\ Shevchenko av., 1, Odessa, Ukraine, 65044 \\ wlebedev29@ rambler.ru \\ ORCID: 0000-0003-891-9708 \\ Chumachenko Tatiana \\ Odessa Polytechnic National University \\ Ph.D., Assosiate Professor \\ Shevchenko av., 1, Odessa, Ukraine, 65044 \\ chumachenko-1981.28@ukr.net \\ ORCID: 0000-0001-6149-4786
}

For references:

Bespalova A., Dashkovskaya O., Faizulyna O., Lebedev V. Chumachenko T. (2021). Cutting stone building materials with cut wheels of cubic boron nitride. Mechanics and Mathematical Methods. 3 (2). 52-63.

Для посилань:

Беспалова А. В., Дашковська О. П., Файзулина О. А., Лебедєв В. Г., Чумаченко Т. В. Розрізання кам’яних будівельних матеріалів відрізними кругами з кубічного нітриду бору. Механіка та математичні методи, 2021. Том 3. Вип. 2. С. 52-63. 